\section{Vegetable Poisons of Africa}

$\mathrm{D}^{\mathrm{R}}$ R. CUFODONTIS has reviewed these numerous vegetable poisons of which the native peoples of Africa have made use from time immemorial in war, hunting, fishing and the destruction of fierce and noxious animals (Scientia, Ser. 3, 32, 1-5; 1938). Though the use of these poisons by the natives has long been recorded by travellers, owing to lack of botanical and chemical knowledge information is often defective. Native methods of extraction are often not only complicated, but also surrounded by mystery and magical ritual, making observation a matter of difficulty.

Strophanthus, a genus widely spread over the whole of tropical Africa, is the principal source of the most powerful African poisons. Its use was recorded so long ago as 1865 by Livingstone on the Zambezi, though the actual plant used was not identified until long after. As an arrow-poison it is fatal to man and most animals, only such large pachyderms as the elephant and hippopotamus being resistant. In West Africa S. hispidus is used, while in Senegal and Guinea its effects have been known to Europeans by fatal experience since the fifteenth century.

The genus Acocanthera, of which half a dozen species are found in different parts of tropical Africa, produces a poison which, acting on the nervous system and by vaso-constriction, is even more powerful than strophanthin, an arrow wound causing death in about one hour. A. ouabaio, confined to Somaliland, and $A$. Schimperi in Abyssinia, Somaliland, Kenya and Tanganyika, produce a powerful poison, effective, it is said, even in pachyderms which resist strophanthin. The adeniums, confined with one exception to Somaliland and the adjacent regions including Socotra, are strongly toxic. They produce a latex which the Somalis use, not for their arrows, but for poisoning bait to kill destructive or dangerous animals near the villages. The active principle is a toxic glucoside which has not yet been analysed. In South Africa a strong arrow poison is extracted from Toxicophlcea Thunbergii and also from the bulbs of one of the Amaryllidæ Buphana disticha, which contains narcissin, hemanthin and a strongly toxic amorphous alkaloid, buphanin. A large family, very rich in poisons, is the Euphorbiacer, which contain five distinct groups of poisons. In Africa the use of poisons extracted from members of this family is confined to the Bushman, Bongos and certain Arabs, while on the east coast at Zanzibar one variety is used in fishing. Few of the leguminous plants are used, and most of these for fishing. It is remarkable that the Strychnos group, which in other continents produces such terrible toxic agents as curare in America and the upas poison of Indonesia, in Africa holds a very subordinate position.

\section{Science News a Century Ago}

\section{Engineering Education at University College, London}

IN the autumn of 1838 , courses in civil engineering were arranged at both King's College, and University College, London. An advertisement in the Athenceum for September 1, 1838, said "Courses of lectures in aid of the system of instruction pursued in the offices of Civil Engineers, will be given at University College in the course of the ensuing Session.

"Every Saturday evening, from 7 to 9, Mr. De Morgan, Professor of Mathematics, will give Lectures and Praxes, the principal object of which will be to teach the application of Arithmetic to the results of Algebra and Geometry. Mr. Sylvester, Professor of Natural Philosophy, will deliver an Elementary Course principally on the Mechanics of Solid Bodies, and the Doctrine of Heat, and their application to the Steam-engine. The Lectures of Professor Sylvester will be given every Wednesday evening from 8 to 10 .

"By attending a Course, or Courses of the Practical Chemistry of Professor Graham, on Monday, Wednesday and Friday from 4 to 5, the Civil Engineer will be exercised in the manipulation of testing and analysing, especially as regards mineral substances used in the arts."

\section{Lyell and the British Association}

ON September 1, 1838, Lyell wrote from his father's house at Kinnordy, Forfarshire, to his father-in-law, Leonard Horner, giving an account of his journey to Newcastle for the meeting of the British Association. He had been through Suffolk and Norfolk geologising, and at Norwich had "avoided all but collectors". The journey northward was made in one steamer from Yarmouth to Hull and then by another from Hull to North Shields. From Shields he made a long excursion to Tynemouth along the shore, went by gig to Cullercoats "where the ninety-fathom dike is laid open in the cliffs, the magnesium limestone on one side and the coal on the other", visited a railway cutting and crossed the Tyne to the Marston Rocks, "where there are lofty perpendicular cliffs of magnesium limestone, and small isolated rocks or needles of the same in the sea". At Newcastle Murchison told him he would be president of the geological section. "All that I saw of the government of the Association," he wrote, "gave me a good idea of the spirit, but no wish to consume my time in taking part in it, to which I am invited, I hear, by being put on the council. Sedgwick was so eloquent; his lecture to 3,000 people on the sea-shore made a great impression."

\section{A Uniform System for Railways}

IN 1838 Nicolas Wood (1793 ?-1865) published the third and last edition of his "Practical Treatise on Rail-roads and Interior Communication in General, etc." In a review of this edition, The Civil Engineer and Architects' Journal in its September number said : "It is now generally admitted that Railways must shortly become the great highways of the kingdom; and it consequently becomes an object of national importance to consider the best modes both of constructing and working them. It appears to us highly desirable that they should all be governed by one law, and all their regulations should be uniform. . . Regretting, as we do, that the opportunity should have been lost of carrying on the railway system from the first on a uniform and consistent plan, we think that much might yet be accomplished towards this very desirable object. For this end we would recommend as a highly desirable measure, the immediate formation of what might be termed a Railway Congress consisting of one Director and the Engineer of each line. . . . Their decision should be binding on all the companies, and when necessary, they might recommend to Parliament bills for the regulation of railways, which from such a body would come supported by the high authority of extensive and practical experience." 